\title{
Biodiversity of epiphytic periphyton in the leaves of the seagrass bed of Talawaan Bajo Estuary, North Sulawesi, Indonesia
}

\author{
NOVA LAURIN ISYE MOUREIN OGI ${ }^{1, \bullet}$, ENDANG YULI HERAWATI ${ }^{2}$, YENNY RISJANI $^{2}$, \\ MOHAMMAD MAHMUDI ${ }^{2}$ \\ ${ }^{1}$ Fisheries and Marine Sciences Graduate Program, Faculty of Fisheries and Marine Science, Universitas Brawijaya. Jl. Veteran, Lowokwaru, Malang \\ 65145, East Java, Indonesia. \\ Tel.: +62-341-553512, Fax.: +62-341-557837, `email: novaogi@gmail.com \\ ${ }^{2}$ Faculty of Fisheries and Marine Science, Universitas Brawijaya. Jl. Veteran, Lowokwaru, Malang 65145, East Java, Indonesia
}

Manuscript received: 30 May 2021. Revision accepted: 18 October 2021.

\begin{abstract}
Ogi NLIM, Herawati EY, Risjani Y, Mahmudi M. 2021. Biodiversity of epiphytic periphyton in the leaves of the seagrass bed of Talawaan Bajo Estuary, North Sulawesi, Indonesia. Biodiversitas 22: 4857-4864. This study aimed to analyze the diversity of epiphytic periphyton on the leaves of the seagrass bed of Talawaan Bajo estuary North Sulawesi Indonesia. The study was performed in three sampling points by using the line transect method with $50 \times 50 \mathrm{~cm}^{2}$. The sampling points were located in front of the residential area, the mangrove forest, and in budo Cape. Seagrass and periphyton communities were analyzed for species density, relative frequency, diversity, evenness, and dominance index. Water quality and heavy metal $\mathrm{Hg}$ were also measured. The results showed that Cymodocea rotundata was the dominant seagrass based on species density and frequency distribution. Periphyton composition on the leaf of $C$. rotundata consisted of Bacillariophyceae (16 genera), Cyanophyceae ( 3 genera), Chlorophyceae (9 genera), Dinophyceae (1 genus), and Rhodophyceae (1 genus). The water quality, such as phosphate, current, nitrate, dissolved oxygen, and $\mathrm{Hg}$ content in the water, contributed to changing the environmental condition of Talawaan Bajo waters. Therefore, the efforts to manage coastal resource conservation in the Talawaan Bajo estuary require more concern from the government and stakeholders of Talawaan Bajo.
\end{abstract}

Keywords: Environmental changes, heavy metal, periphyton diversity, seagrass ecosystem

\section{INTRODUCTION}

Coastal and marine areas play a crucial role in Indonesia as the primary provider of natural resources and environmental services (Sugianti et al. 2018). They also host the immeasurable biodiversity of marine life. One of the marine and coastal habitats is Seagrass beds. Seagrass beds have many functions, including providing physical habitat for small invertebrates such as shrimp, crabs and other crustaceans, small fish and juveniles of larger fish (Nadiarti et al. 2012). The root and rhizome of seagrass could stabilize sediments, reduce erosion and enhance water quality and cycling of nutrients (Ambo-Rappe 2016). It also plays a role in carbon sequestration (Macreadie et al. 2012) and decreasing the bacterial pathogen in the marine ecosystem (Lamb et al. 2017). Habitat provided by seagrass beds also acts as a nursery ground for numerous juvenile fish (Saenger et al. 2013).

Seagrasses also provide essential ecological linkages with the adjacent coral reefs and/or mangroves, in which seagrass communities support the existence of coral reefs through the export of organic materials (Campbell et al. 2011) and also provide grazing grounds and/or nurseries for coral reef fishes and another reef fauna (Nordlund et al. 2014; Flaherty-Walia et al. 2017). The presence of seagrass beds is closely related to the abundance and diversity of marine organisms (Ambo-Rappe 2016), especially Periphyton (Razali et al. 2019) which serve as a vital food source for amphipods and gastropods (Segovia-Rivera and
Valdivia 2016). Therefore, the presence of a seagrass bed is crucial for the sustainability of marine biodiversity.

Although seagrass ecosystems have many physical and ecological functions, their decline has been reported in many countries worldwide (Kawaroe et al. 2010; Shelton et al. 2016). Natural disturbance, such as grazing and storm (van Tussenbroek et al. 2014) was the common factor that is an inherent part of the seagrass ecosystem dynamic. However, anthropogenic factors (Otero 2015), such as eutrophication (Schmidt et al. 2012), overfishing (Pitanga et al. 2012) and conversion of coastal habitats, were the greatest cause of seagrass disturbance. In other words, the increase of pollutants in the coastal area also contributes to seagrass diversity. Of course, these kinds of seagrass threats will lead to the extinction of some organisms at a higher trophic level (Ambo-Rappe 2016). Hence, seagrass conservation is needed to cope with this case.

The population which is still adapted to environmental changes and has a symbiosis with seagrass is periphyton. Periphyton is a micro-ecosystem composed of a mixture of autotrophic and heterotrophic microorganisms attached to a matrix of organic detritus (Yadav et al. 2017). Periphytons living on the seagrass leaves are the source of autochthonous energy in the water and support the primary producer of the seagrass bed. Furthermore, periphytons can be used as a bio-indicator of water quality (Khan and Firuza et al. 2012) and environmental changes (Sugianti et al. 2018). However, Indonesia's periphyton abundance and diversity study were limited to Bangka Belitung (Rosalina 
et al. 2018a, 2018b, 2019a, 2019b).

The study of the importance of seagrass ecosystems and the impacts of anthropogenic disturbances is urgently needed to improve the management and conservation. Therefore, this study aimed to analyze the diversity of epiphytic periphyton on the leaves of the seagrass bed of Talawaan Bajo estuary North Sulawesi Indonesia and demonstrate the estuarine environmental condition based on the oceanographic parameters. This study is expected to determine the relationship of periphyton diversity and environmental changes, especially heavy metal $(\mathrm{Hg})$ in the Talawaan Bajo estuary.

\section{MATERIALS AND METHODS}

\section{Study area}

This study was carried out in the estuary of Talawaan Bajo, North Sulawesi, Indonesia (Figure 1). Observations on seagrass occurrence were focused on three stations, in front of the residential area (Station 1), in front of a mangrove forest (Station 2), and around Budo Cape (Station 3) (Figure 1).

\section{Field sampling and data collection}

\section{Seagrass}

Samples collection was carried out during the low tide period in coherence with the full moon phase. The sample collection was performed using the line transect method with $50 \times 50 \mathrm{~cm}^{2}$. Three 50 meter-transect lines were randomly set perpendicular to the coastal area depending upon the density of seagrass beds in the study site. A total of thirty quadrats (10 quadrats per transect) were employed. All samples covered in the quadrat were separated, placed in plastic bags, then brought to the Laboratory of Faculty of Fisheries and Marine Science, Sam Ratulangi University, for further analysis. Species identification was referred to Lanyon (1985) and Larkum et al. (2006) methods.

\section{Periphyton}

Epiphytic periphyton was collected from seagrass leaves. The collections were obtained by cutting 2 sheets of dominant seagrass leaves from each transect in all study sites. The periphytons were collected by gently scraping the leaf surface as wide as $10 \mathrm{~cm}^{2}$ at the base, the mid, and the tip of the leaves. The scraped material was then put in a sample bottle, labelled, and preserved in Lugol's solution (Merck KGaA, Darmstadt, Germany). The periphytons were observed under the microscope with magnification 400x using the Luckey Drop method. The identification was performed according to the classification literature book of Bold and Wynne (1985) and Kozloff (1990).

\section{Data analysis}

\section{Seagrass}

Seagrass community analyses focused on species density, relative frequency, diversity, evenness, and dominance. Species density was estimated using formula 1:

$$
\mathrm{Di}=\frac{\mathbb{N i}}{\mathrm{A}}
$$

Where, $\mathrm{D} i$ is the number of individuals i per unit area, $\mathrm{Ni}$ is the number of individuals $j$ in quadrat transect, and $\mathrm{A}$ is the width of quadrat transect.
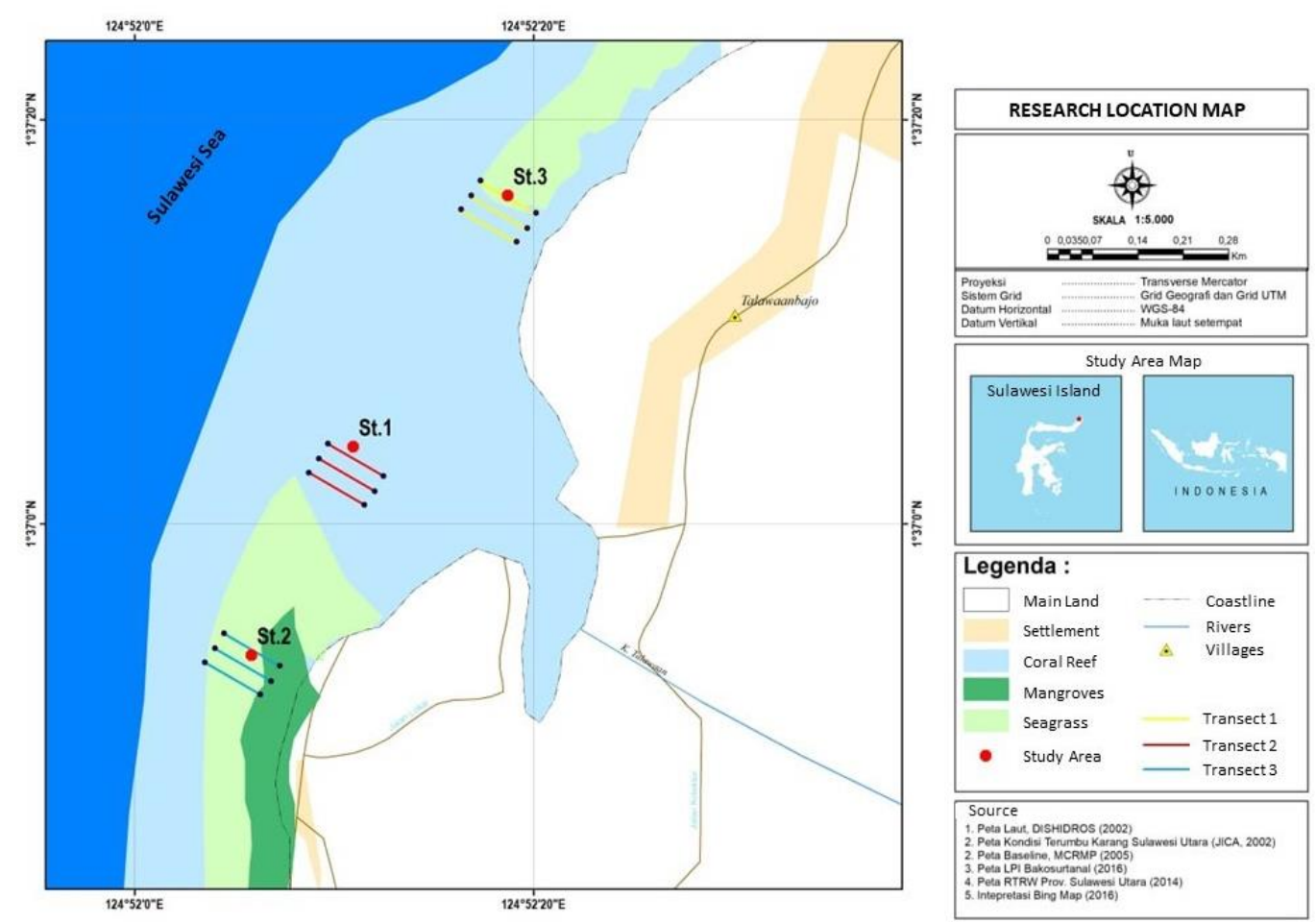

Figure 1. Research location map of Talawaan Bajo, North Sulawesi, Indonesia 
Relative frequency (RFi) was calculated as follows:

$$
\mathrm{RFi}=\frac{\mathrm{Fi}}{\sum_{\mathrm{i}=1}^{\mathrm{P}} \mathrm{Fi}} \times 100
$$

Where, $\mathrm{RFi}$ is relative frequency, $\mathrm{Fi}$ is frequency species-i, and $\sum_{I=\mathbb{1}}^{F} F i$ is the number of frequencies of all species.

Species diversity applied the Shannon-Wiener index to measure the community abundance based on the number of species and number of individuals per species.

$$
H^{T}=-\sum_{i=1}^{g} \frac{p i}{\mathbb{N}} x \ln \frac{p i}{\mathbb{N}}
$$

Where, $\mathrm{H}^{\prime}$ is diversity index, $\mathrm{Pi}$ is the proportion of the number of species $\mathrm{i}$ to total the number of individuals $(\mathrm{ni} / \mathrm{N}), \mathrm{N}$ is the total number of individuals of all species, $\mathrm{S}$ is the number of species taxa.

Species evenness (E) was calculated by dividing the diversity index and the maximum diversity index to measure the ecosystem equilibrium. Species evenness estimation using formula 4 :

$$
\begin{aligned}
& E=\frac{H^{\prime}}{H \max x} \\
& H \max =\ln (S)
\end{aligned}
$$

Where, $\mathrm{E}$ is the Shannon evenness index, H' is the Shannon-Wiener diversity index, H'max is the maximum diversity index, and $\mathrm{S}$ is the number of species.

Dominance index employed Simpson dominance index (D) to describe the most genus/species occupying a certain area Dominance was calculated using the following formula:

$$
D=\sum_{i=1}^{g} \frac{\text { nil(ni-1) }}{N(N-1)}
$$

Where, D is Simpson dominance index, ni is the number of species $\mathrm{i}$, and $\mathrm{N}$ is the total number of individuals of all species.

\section{Periphyton}

The periphyton density was estimated based on plankton calculation by modifying Lackey Drop Microtransecting Methods (APHA 1989). Species diversity, evenness, and dominance of the periphyton were also assessed.

\section{Environmental variables}

Measurements of water quality parameters focused on temperature, current water, depth, substrate, turbidity, $\mathrm{pH}$, salinity, dissolved oxygen (DO), phosphate, nitrate, and mercury $(\mathrm{Hg})$. Environmental measurement was conducted with three replications. The bottom sediment was collected using one unit of Sediment Grab. Temperature, current water, depth, $\mathrm{pH}$, salinity and DO were measured using U50 Multiparameter Water Quality Checker (Horiba, Ltd., Japan). The Brusin method with a spectrophotometer (SNI 06-2480-1991) at a wavelength of $410 \mathrm{~nm}$ was used to determine nitrate levels in the range of $0.1 \mathrm{mg} / \mathrm{L}-2.0$ $\mathrm{mg} / \mathrm{L}$. Determination of phosphate levels was carried out by the ascorbic acid spectrophotometer method (SNI 066989.31-2005) in the range of $0.0 \mathrm{mg} \mathrm{P} / \mathrm{L}$ to $1.0 \mathrm{mg} \mathrm{P} / \mathrm{L}$. The ascorbic acid spectrophotometer method (SNI 066989.31-2005) was used to measure phosphate levels in the range of $0.0 \mathrm{mg} \mathrm{P} / \mathrm{L}$ to $1.0 \mathrm{mg} \mathrm{P} / \mathrm{L}$. The production of a blue-colored phosphomolybdate complex is the basis of this approach. The Molybdenum complex is further reduced using ascorbic acid to produce a blue color. The intensity of the color produced is proportional to the phosphorus content. A spectrophotometer was used to measure the blue color produced at a wavelength of 700nm-880nm. Mercury ( $\mathrm{Hg}$ ) content was analyzed using an Atomic Adsorption Spectrophotometer (AAS).

A correlation analysis was performed to identify the study site with the environmental characteristics that affect seagrass and periphyton biodiversity. A principal component analysis (PCA) was used to determine the correlation between oceanographic parameters with seagrass and periphyton.

\section{RESULTS AND DISCUSSION}

\section{Community structure of seagrass}

This study found 6 species of seagrasses belonging to 2 families and 7 genera in two different sites of Talawaan Bajo estuary (Table 1). Halodule uninervis was the

\begin{tabular}{|c|c|c|c|c|c|c|c|c|c|c|}
\hline \multirow{2}{*}{ Species } & \multirow{2}{*}{ Code } & \multicolumn{3}{|c|}{ Station 1} & \multicolumn{3}{|c|}{ Station 2} & \multicolumn{3}{|c|}{ Station 3} \\
\hline & & 1.1 & 1.2 & 1.3 & 2.1 & 2.2 & 2.3 & 3.1 & 3.2 & 3.3 \\
\hline Enhalus acoroides & $\mathrm{Ea}$ & - & - & - & + & + & + & - & + & + \\
\hline Thalassia hemprichii & Th & - & - & - & - & + & + & + & + & + \\
\hline Cymodocea rotundata & $\mathrm{Cr}$ & - & - & + & + & + & + & + & + & + \\
\hline C. serrulata & $\mathrm{Cs}$ & - & - & - & + & + & + & + & + & + \\
\hline Halodule uninervis & $\mathrm{Hu}$ & + & + & + & + & + & + & + & + & + \\
\hline Halophila ovalis & Ho & - & - & - & + & + & + & - & - & - \\
\hline No. species & & 1 & 1 & 2 & 5 & 6 & 6 & 4 & 5 & 5 \\
\hline
\end{tabular}
common seagrass found in all stations (Table 1), whereas Halophila ovalis is the rare seagrass since it was only found in station 2 .

Table 1. Seagrass distribution in Talawaan Bajo estuary, North Sulawesi, Indonesia

Note: (+) present; (-) absent 


\section{Seagrass density and relative density}

Seagrass density is highly correlated with space and bottom substrates (McCloskey and Unsworth 2015). The presence of a suitable substrate could make the seagrass grow well. Most seagrass species develop in sandy to the muddy bottom, but some other species grow on corals, such as Phyllospadix spp, Thalassodendron spp and Posidonia oceanica (Guannel et al. 2016).

In all study sites, the seagrass density was varied, as shown in Figure 2. The lowest was found in the station I occupied by 2 species, $C$. rotundata and $H$. uninervis. At the same time, the highest was recorded in station II with mixed vegetations consisting of $E$. acaroides, $T$. hemprichii, C. rotundata, C. serrulata, $H$. uninervis, and $H$. ovalis.

\section{Species frequency}

Species frequency is the number of times a species occurs in the given sampling point. The high frequency of species, in general, has higher adaptation to different environmental conditions. However, a species with a highdensity value cannot be guaranteed to have a highfrequency value. The relative frequency (RFi) of seagrass species is presented in Figure 3, in which $C$. rotundata has the RFi of 35\% since it was found evenly in all stations. The lowest RFi value was observed in H.ovalis, with an RFi value of $4 \%$, only found in stations 2 and 3 .

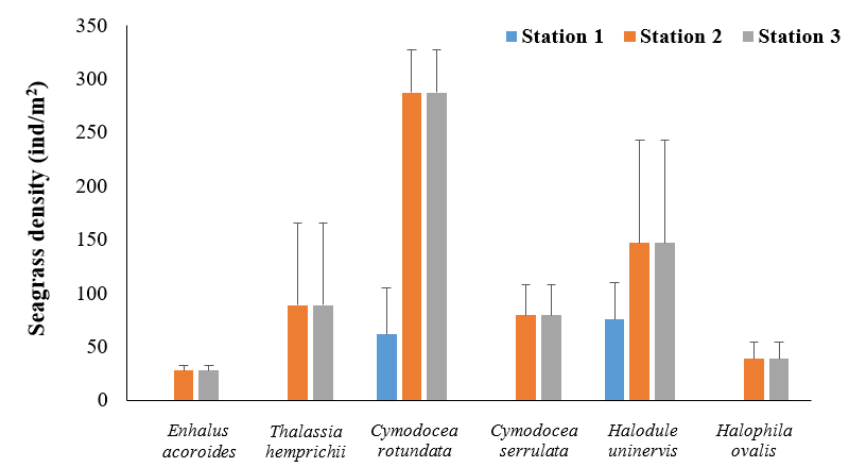

Figure 2. Seagrass density (ind $/ \mathrm{m}^{2}$ ) in Talawaan Bajo estuary, North Sulawesi, Indonesia

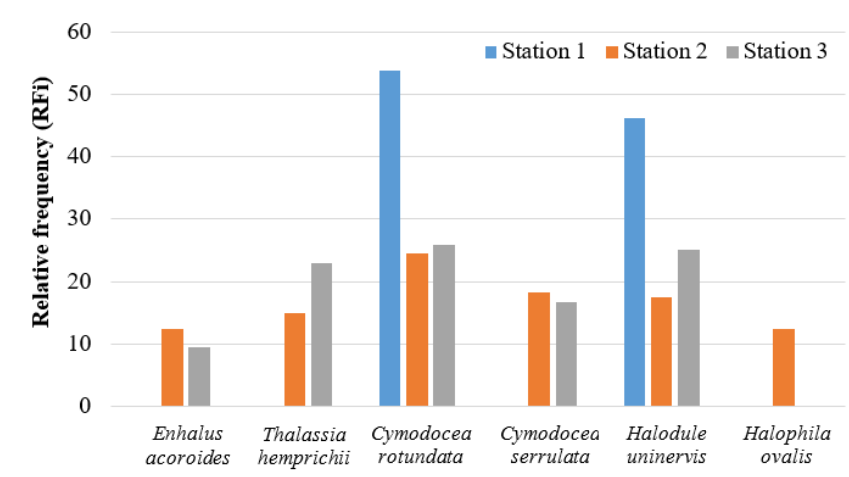

Figure 3. Relative frequency (RFi) of seagrass in Talawaan Bajo estuary, North Sulawesi, Indonesia
Diversity index $\left(H^{\prime}\right)$, evenness $(E)$, and dominance $(D)$

The higher index value of diversity showed high species variations in the community, not dominated by one or more specific species. Evenness index ranges from 0 to 1 , in which $\mathrm{E}<0.4$ indicates the ecosystem under pressure and low evenness, $\mathrm{E}=0.4-0.6$ is moderate evenness and low stability, and E>0.6 reflects stable ecosystem and high evenness. The diversity analysis is presented in Table 2 .

\section{Community structure of epiphytic periphyton on Cymodocea rotundata \\ Periphyton composition}

The presence of periphyton is highly dependent on sunlight intensity, temperature, current, substrate type and nutrient availability. Uniform temperature distribution in the water and light intensity helps the plant to photosynthesize effectively up to the sea bottom. Periphytons were found on all leaf surfaces of $C$. rotundata with different densities. Based on laboratory observations, it revealed that the periphyton composition on the leaf varied with stations. This study found 5 classes, Bacillariophyceae (16 genera), Cyanophyceae (3 genera), Chlorophyceae (9 genera), Dinophyceae (1 genus), and Rhodophyceae (1 genus) (Table 3).

Bacillariophyceae had a diverse genera composition among the classes. Most of the genus Bacillariophyceae can adapt to various water environments. In the worst condition, these family members can survive in environments with more mucous. Besides, most of the genera of Bacillariophyceae produce gelatin stalk-like tools to adhere to the specific substrate. With this assistance, members of Bacillarriophyceae can sustain the strong currents (Kuczynska et al. 2015). The periphyton composition is also remarkably affected by the substrate type for attachment.

The epiphytes of Bacillariophyceae (Diatom) on the seagrass leaf are genus Nitzschia and Cocconeis (Al-Harbi 2017). Since the periphyton composition is almost the same on various seagrass leaves, the present study concluded that the leaves of the seagrasses had similar characteristics as the substrate for the periphyton. The periphyton composition on the seagrass leaf is strongly influenced by the seagrass morphology, age, position or habitat. The seagrass possessing large leaf-like E. acoroides is more selected by the periphyton than the small leaf because the seagrass of large leaves will have a more stable substrate condition. Similarly, older seagrasses will hold different periphyton composition and density than the younger since the attachment process and colony formation of the periphyton need enough time.

Table 2. Seagrass diversity index (H'), evenness index (E), and dominance index (D)

\begin{tabular}{lccc}
\hline \multirow{2}{*}{\multicolumn{1}{c}{ Index }} & \multicolumn{3}{c}{ Station } \\
\cline { 2 - 4 } & I & II & III \\
\hline H' = Shannon Diversity Index & 0.56 & 1.55 & 1.15 \\
E = Similarity Index & 0.80 & 0.87 & 0.72 \\
D = Dominant Index (Simpson's) & 0.63 & 0.26 & 0.37 \\
H-max = Diversity Maximum & 0.69 & 1.79 & 1.61 \\
D' = Simpson Diversity Index & 0.37 & 0.74 & 0.63 \\
\hline
\end{tabular}


Table 3. Periphyton distribution in Talawaan Bajo estuary, North Sulawesi, Indonesia

\begin{tabular}{|c|c|c|c|}
\hline \multirow{2}{*}{ Periphyton } & \multicolumn{3}{|c|}{ Station } \\
\hline & $\mathbf{I}$ & II & III \\
\hline \multicolumn{4}{|l|}{ Chlorophyta } \\
\hline Chlorella & + & + & - \\
\hline Cylindrocapsa & + & + & + \\
\hline Echinosphaerella & + & - & - \\
\hline Gongrosira & - & + & - \\
\hline Mougeotia & - & + & - \\
\hline Prasinocladus & + & - & - \\
\hline Scenedesmus & + & + & + \\
\hline Ulva flexuosa & + & - & + \\
\hline Stigeoclonium & + & + & + \\
\hline \multicolumn{4}{|l|}{ Bacillariophyta } \\
\hline Achnanthes & - & + & - \\
\hline Cocconeis & + & + & + \\
\hline Coscinodiscus & + & - & - \\
\hline Cyclotella & + & + & + \\
\hline Cymatopleura & + & + & + \\
\hline Cymbella & + & + & + \\
\hline Diatoma & + & + & + \\
\hline Fragilaria & - & + & + \\
\hline Gyrosigma & - & + & - \\
\hline Melosira & + & + & + \\
\hline Navicula & + & + & + \\
\hline Nitzschia & + & + & + \\
\hline Pinnularia & + & + & + \\
\hline Surirella & + & + & + \\
\hline Synedra & - & + & + \\
\hline Tabellaria & + & + & + \\
\hline \multicolumn{4}{|l|}{ Cyanophyta } \\
\hline Agmenelum & - & + & - \\
\hline Oscillatoria & + & + & + \\
\hline Plectonema & + & - & + \\
\hline \multicolumn{4}{|l|}{ Dinophyta } \\
\hline Gymnodinium & + & - & + \\
\hline \multicolumn{4}{|l|}{ Rhodophyta } \\
\hline Sirodotia & - & + & + \\
\hline
\end{tabular}

Notes: $+=$ present, $-=$ absent

In the station I, II and III, the highest density of periphyton was Cocconeis $\left(3,378,045.6 \mathrm{cell} / \mathrm{cm}^{2}\right)$, Nitzschia $\left(751,549.8\right.$ cell $\left./ \mathrm{cm}^{2}\right)$, Navicula $(7,096,514$ cell $/ \mathrm{cm}^{2}$ ), respectively. The mostly periphytons belonged to Bacillariophyceae as major epiphytes on the seagrass. The seagrass density could directly or indirectly impact the presence and density of periphyton due to its close relationship with the substrate stability (seagrass leaf) from flushing effect, water circulation, and the chance of the periphyton in obtaining sunlight for photosynthesis (McCloskey and Unsworth 2015).

McCloskey and Unsworth (2015) stated that the leaf length and the seagrass density could affect the distribution and the abundance of seagrass-associated biota. Factors influencing the change in seagrass beds could also determine the periphyton distribution and abundance. The diversity index in this study describes the richness/number of periphyton genera, in which the higher the diversity index, the higher the periphyton variations. Station II had a diversity index of 2.759, indicating that individual distribution was low and ecological pressures were high. In contrast, station III, with a diversity index of 3.006, reflected high individual distribution and had high ecological pressures (Table 4). It could be derived from the higher periphyton genera in station III than in other stations. The physical factor, such as current, highly affects the periphyton attachment. Station III had the lowest winds, so periphyton could strongly attach and develop well in this area.

The highest evenness index is station I (0.647), followed by station III (0.576) and station II (0.497). The high evenness index indicates that the individual distribution of each genus/species in the community is uniform and followed by a low dominance index, 0.1370.191 . The dominance index exhibited no species that significantly dominate other species. It is supported by the distribution index $<1.0$, reflecting uniform distribution or random distribution.

\section{PCA analysis-based relationship of oceanographic parameters with seagrass and periphyton}

Parameters used for PCA analysis were periphyton density, seagrass density, dissolved oxygen, salinity, phosphate $(\mathrm{P})$, nitrate $(\mathrm{N})$, temperature $(\mathrm{T})$, and current. These parameters were integrated to obtain a matrix value of the relationship among parameters and the cumulative variance value. The considered variables were environmental components and the number of seagrass individuals in 3 stations. This analysis applied 2 axes that gave a significant contribution to the water characteristics. In the environmental characteristics, the first axis (F1) gave a contribution of $76.65 \%$ (Figure 3 ) to the entire environmental parameter characteristics in all stations, wherefrom the total value, phosphate contributed $27.7 \%$, current velocity $27.2 \%$, nitrate $23.0 \%$, and dissolved oxygen $22.0 \%$. In contrast, water temperature and salinity did not give a remarkable contribution with the same value in all stations. Furthermore, for seagrass species characteristics, the first axis contributed $70.69 \%$ (Figure 4) to the entire characteristics of the seagrass species individual numbers. The highest was found in $T$. hemprichii $23.0 \%$, and the lowest in H. ovalis $4.8 \%$.

Figure 3 demonstrates the different species and individuals affected by phosphate content, current, nitrate, and dissolved oxygen in all stations. Water temperature and salinity do not influence the number of species and individuals indicated with similar values. Seagrass density affects the presence and the density of periphyton. It is closely related to substrate stability (seagrass leaf) from flushing effect and water circulation on the ability to absorb nutrients and chance to obtain the sunlight for photosynthesis. Therefore, the more the seagrasses occur, the higher the possibility of the periphyton attaching. Interspecific competition of periphyton for space, sunlight, and food could also determine the periphyton attachment on the leaf, where the more potent species would have a high abundance. 
Table 4. Density (N), diversities (H'), dominance (D), and evenness index (E) of Periphyton from Talawaan Bajo, North Sulawesi, Indonesia

\begin{tabular}{lccc}
\hline \multirow{2}{*}{\multicolumn{1}{c}{ Index }} & \multicolumn{3}{c}{ Station } \\
\cline { 2 - 4 } & I & II & III \\
\hline Density (N) & 13.695487 & 38.921 .719 & 26.456 .993 \\
Diversity (H') & 2.864 & 2.759 & 3.006 \\
Dominance (D) & 0.137 & 0.191 & 0.151 \\
Evenness (E) & 0.647 & 0.497 & 0.576 \\
\hline
\end{tabular}

Mabrouk et al. (2014) found that the epiphyte abundance on the seagrass individual varied depending on the bottom's distance. Our observation indicated that the periphyton density on $C$. rotundata was higher than the other species. The possible reason is $C$. rotundata has shorter leaf morphology, and the distance is near the bottom, so the opportunity of the periphyton attachment occurs not only because of the periphyton's colonization process but also the effect of the periphyton's colonization process water movement that brings the sediment and benthic organisms. In addition, suitable physical and chemical conditions for the seagrass and periphyton growth in the seagrass ecosystem with different densities could also increase the abundance of several periphyton species.

PCA analysis revealed that seagrass density has a negative correlation with current, nitrate, and phosphate. The denser the seagrass, the lower the current speed, nitrate, and phosphate will be. Huang et al. (2019) also claimed that shallow waters greatly influenced slowing down the current. Current velocity is considered to be related to the periphyton community development in the seagrass ecosystem, in which it could determine the periphyton community-building organisms.

Strong currents in the low-density seagrass area make the seagrass leaves upright to penetrate the water, while in the high-density seagrass area, the sunlight could only reach the water surface. It concerns photosynthesis done by the seagrass and the periphyton. Current velocity indirectly affects the nutrients absorbed by the seagrass root. The oxygen transport to the root could aerobically result in metabolisms so that the nutrient absorption could increase. Our observations agree that the growth of larger plants with extensive roots and rhizome systems will benefit the metabolism. Gillis et al. (2014) found that the concentration of organic materials in the sediment with seagrasses was higher than that in the sediment without seagrass. This high organic content will also affect the organism abundance, including the seagrass-associated periphyton.

\section{Environmental condition}

Aquatic environmental conditions affect all forms of all living species in water, directly or indirectly. Physical and chemical characteristics also influence the community structure of living biota in the water, especially the seagrass bed. The aquatic environmental conditions of the Talawaan Bajo estuary were still perfect for the seagrass to grow. Station $I$ is near the local residential area and used as a mooring site for the fishermen's boats. Station II is a mangrove forest as a nutrient trap area, while station III is downstream of the river. The aquatic environmental condition in the present study reflects the relationship between the seagrass characteristics and human activities in the estuary of Talawaan Bajo. These values could also describe the water quality supporting the seagrass density (Table 5).

\section{Mercury (Hg) concentration}

Table 6 presented the $\mathrm{Hg}$ concentration obtained from AAS analysis. The normal and maximum concentration of heavy metal mercury $(\mathrm{Hg})$ entering the aquatic environment is $0.1 \mathrm{ppb}$ and $1.2 \mathrm{ppb}$, respectively (APHA 1989). The present study found higher concentrations than that of normal and maximum levels (Table 6). The waste from the mining industry (which requires Mercury $(\mathrm{Hg})$ for gold refining) is channeled through the Talawaan watershed, where it will eventually be deposited and absorbed by the Talawaan Bajo estuary waters.
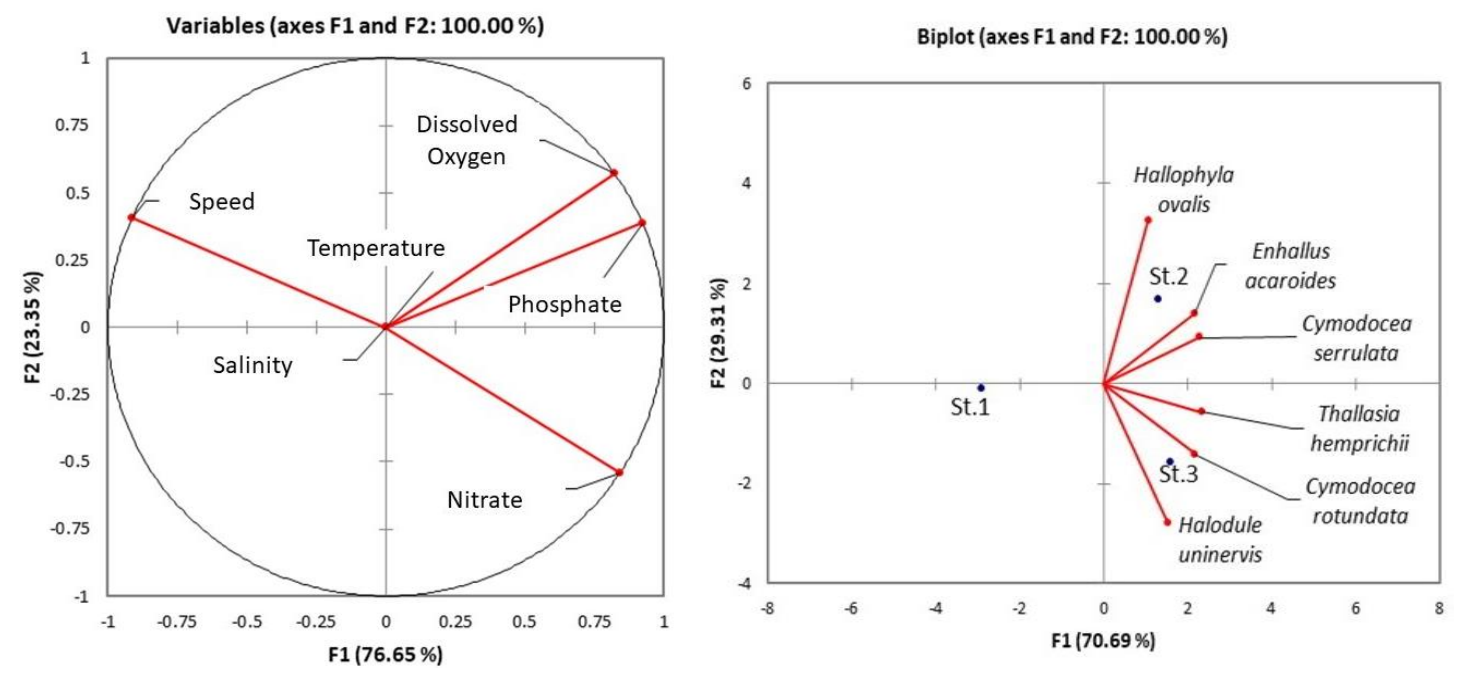

Figure 4. Projection of station and benthic component in two dimensions (axis 1 and axis 2) using PCA 
Table 5. Several oceanographic parameters in the study sites

\begin{tabular}{|c|c|c|c|c|c|c|c|}
\hline Station & Transect & $\begin{array}{l}\text { Temp } \\
\left({ }^{\circ} \mathrm{C}\right)\end{array}$ & $\begin{array}{c}\text { Salinity } \\
\text { (\%o) }\end{array}$ & $\begin{array}{c}\text { Current } \\
(\mathbf{m} / \mathbf{s})\end{array}$ & $\begin{array}{c}\text { Dissolved } \\
\text { oxygen (ppm) }\end{array}$ & $\begin{array}{l}\text { Nitrate } \\
(\mathrm{mg} / \mathrm{L})\end{array}$ & $\begin{array}{c}\text { Phosphate } \\
(\mathrm{mg} / \mathrm{l})\end{array}$ \\
\hline \multirow[t]{4}{*}{ I } & I & 32.00 & 31.25 & 0.02 & 4.85 & 2.0010 & 0.0000 \\
\hline & II & 31.86 & 32.40 & 0.02 & 4.86 & 2.1512 & 0.0031 \\
\hline & III & 31.98 & 32.25 & 0.02 & 4.86 & 2.2035 & 0.0000 \\
\hline & Mean & 31.95 & 31.96 & 0.02 & 4.86 & 2.1186 & 0.00103 \\
\hline \multirow[t]{4}{*}{ II } & I & 31.86 & 32.85 & 0.02 & 3.55 & 1.8584 & 0.0062 \\
\hline & II & 30.03 & 31.82 & 0.02 & 4.85 & 1.8526 & 0.0060 \\
\hline & III & 29.92 & 32.74 & 0.02 & 4.85 & 2.0670 & 0.0061 \\
\hline & Mean & 30.60 & 32.47 & 0.02 & 4.42 & 1.9260 & 0.00610 \\
\hline \multirow[t]{4}{*}{ III } & I & 30.01 & 30.75 & 0.03 & 5.44 & 2.1029 & 0.0000 \\
\hline & II & 30.00 & 31.82 & 0.03 & 5.43 & 2.1565 & 0.0000 \\
\hline & III & 30.06 & 32.74 & 0.03 & 5.44 & 2.3909 & 0.0016 \\
\hline & Mean & 30.02 & 31.77 & 0.03 & 5.44 & 2.2168 & 0.00053 \\
\hline
\end{tabular}

Table 6. Mean mercury concentration (ppm)

\begin{tabular}{lccc}
\hline \multirow{2}{*}{\multicolumn{1}{c}{ Type }} & \multicolumn{3}{c}{ Station } \\
\cline { 2 - 4 } & I & II & III \\
\hline Seagrass & 3.11 & 4.56 & 4.75 \\
Periphyton & 7.95 & 20.02 & 24.17 \\
\hline
\end{tabular}

The present study found 6 species of seagrasses $(E$. acoroides, T. hemprichii, $C$. rotundata, $C$. serrulate, $H$. uninervis, and $H$. ovalis) in Talawaan Bajo estuary with dominant species of $C$. rotundata. The periphyton composition on the leaf of $C$. rotundata, consisting of Bacillariophyceae (16 genera), Cyanophyceae (3 genera), Chlorophyceae (9 genera), Dinophyceae (1 genus), and Rhodophyceae (1 genus), respectively. In addition, the water quality, such as phosphate, current, nitrate, and dissolved oxygen, and $\mathrm{Hg}$ content in the water, contributed to changing the environmental conditions in Talawaan Bajo waters. In conclusion, the efforts to manage coastal resource conservation in the Talawaan Bajo estuary requires more concern from the government and stakeholders of Talawaan Bajo.

\section{ACKNOWLEDGEMENTS}

The authors thank to Brawijaya University, Malang, Indonesia for facilitated this research.

\section{REFERENCES}

Al-Harbi SM. 2017. Epiphytic microalgal dynamics and species composition on brown seaweeds (Phaeophyceae) on the Northern Coast of Jeddah, Saudi Arabia. J Oceanogr Mar Biol 5: 1-9. DOI: 10.4172/2572-3103.1000153.

Ambo-Rappe R. 2016. Differences in richness and abundance of species assemblages in tropical seagrass beds of different structural complexity. J Environ Sci Technol 9 (3): 246-256. DOI: 10.3923/jest.2016.246.256.

APHA. 1989. Standard Methods for the Examination of Water and Wastewater. Port City Press, Baltimore, Maryland.
Bold HC, Wynne MJ. 1985. Introduction to the Algae. Prentice-Hall Inc., New Jersey.

Campbell SJ, Kartawijaya T, Sabarini EK. 2011. Connectivity in reef fish assemblages between seagrass and coral reef habitats. Aquat Biol 13: 65-77. DOI: 10.3354/ab00352.

Flaherty-Walia KE, Pittinger B, Switzer TS, Keenan SF. 2017. Seagrass habitats as nurseries for reef-associated fish: Evidence from fish assemblages in and adjacent to a recently established no-take marine reserve in dry Tortugas National Park, Florida, USA. Gulf Caribbean Res 28: 15-28. DOI: $10.18785 / \mathrm{gcr} .2801 .06$.

Gillis LG, Ziegler AD, van Oevelen D, Cathalot C, Herman PMJ, Wolters JW, Bouma TJ. 2014. Tiny is mighty: Seagrass beds have a large role in the export of organic material in the tropical coastal zone. Plos One 9 (11): e111847. DOI: 10.1371/journal.pone.0111847.

Guannel G, Arkema K, Ruggiero P, Verutes G. 2016. The Power of three: Coral reefs, seagrasses and mangroves protect coastal regions and increase their resilience. Plos One 11 (7): e0158094. DOI: 10.1371/journal.pone.0158094.

Huang C-F, Li Y-W, Taniguchib N. 2019. Mapping of ocean currents in shallow water using moving ship acoustic tomography. J Acoust Soc Am 145 (2): 12-20. DOI: 10.1121/1.5090496.

Kawaroe M, Prartono T, Sanuddin A, Wulansari D, Augustine D. 2010. Mikroalga Potensi dan Pemanfaatannya untuk Produksi Bio Bahan Bakar. IPB Press, Bandung. [Indonesian]

Khan IN, Firuza BM. 2012. Biological assessment of water pollution using Periphyton productivity and standing crop in the Linggi River, Malaysia. Intl Rev Hydrobiol 97 (2): 124-156. DOI: 10.1002/iroh.201111456.

Kozloff E. 1990. Invertebrates. Saunder College Publishing, New York.

Kuczynska P, Jemiola-Rzeminska M, Strzalka K. 2015. Photosynthetic pigments in diatoms. Mar Drugs 13 (9): 5847-5881. DOI: 10.3390/md13095847.

Lamb JB, van de Water JAJM, Bourne DG, Altier C, Hein MY, Fiorenza EA, Abu N, Jompa J, Harvell CD. 2017. Seagrass ecosystems reduce exposure to bacterial pathogens of humans, fishes, and invertebrates. Science 355 (6326): 731-733. DOI: 10.1126/science.aal1956.

Lanyon J. 1985. Guide to the Identification of Seagrasses in the Great Barrier Reef Region. Great Barrier Reef Marine Park Authority (GBRMPA), Queensland.

Larkum A, Orth RJ, Duarte CM. 2006. Seagrass Biology, Ecology and Conservation. Springer, New York.

Mabrouk L, Brahim MB, Hamza A, Mahfoudhi M, Bradai MN. 2014. A comparison of abundance and diversity of epiphytic microalgal assemblages on the leaves of the seagrasses Posidonia oceanica (L.) and Cymodocea nodosa (Ucria) Asch in Eastern Tunisia. J Mar Biol 2014 (3-4): 1-10. DOI: 10.1155/2014/275305.

Macreadie PI, Bairda ME, Trevathan-Tacketta SM, Larkuma AWD, Ralph PJ. 2012. Quantifying and modelling the carbon sequestration capacity of seagrass meadows - A critical assessment. Mar Pollut Bull 83: 430-439. DOI: 10.1016/j.marpolbul.2013.07.038. 
McCloskey RM, Unsworth RKF. 2015. Decreasing seagrass density negatively influences associated fauna. Peer J 3: e1053. DOI 10.7717/peerj. 1053 .

Nadiarti, Riani E, Djuwita I, Budiharsono S, Purbayanto A, Asmus H. 2012. Challenging for seagrass management in Indonesia. J Coast Develop 15 (3): 234-242.

Nordlund LM, de la Torre-Castro M, Erlandsson J, Conand C, Muthiga N, Jiddawi N, Gullstrom M. 2014. Intertidal zone management in the western indian ocean: Assessing current status and future possibilities using expert opinions. Ambio 43 (8): 1006-1019. DOI: 10.1007/s13280-013-0465-8.

Otero E. 2015. Characterization of Mechanical Damage to Seagrass Beds in La Cordillera Reefs Natural Reserve (Report No. 2006-000951). Conservation and Management of Puerto Rico's Coral Reefs, Florida.

Pitanga ME, Montes MJE, Magalhães KM, Reis TNV. 2012 Quantification and classification of the main environmental impacts on a Halodule wrightii seagrass meadow on a tropical island in northeastern Brazil. An Acad Bras Cienc 84 (1): 35-42. DOI: 10.1590/S0001-37652012000100005

Razali AC, Watiniasiha NL, Dewi APWK. 2019. Diversitas perifiton pada daun lamun Enhalus acoroidesdi Perairan Karangsewu, Teluk Gilimanuk, Taman Nasional Bali Barat. Curr Trends Aquat Sci 2 (2): 25-32. [Indonesian]

Rosalina D, Herawati E, Musa M, Risjani Y. 2018a. Lead (Pb) adsorption in roots, rhizomes, and leaves of seagrass Cymodocea serrulata. Fresenius Environ Bull 27 (12 A): 9156-9166.

Rosalina D, Herawati EY, Risjani Y, Musa M. 2018b. Keanekaragaman spesies lamun di Kabupaten Bangka Selatan Provinsi Kepulauan Bangka Belitung. EnviroScienteae 14 (1): 21-28. DOI: 10.20527/es.v14i1.4889. [Indonesian]

Rosalina D, Herawati EY, Musa M, Sofarini D, Risjani Y. 2019a. Anatomical changes in the roots, rhizomes and leaves of seagrass (Cymodocea serrulata) in response to lead. Biodiversitas 20 (9): 2583-2588. DOI: 10.13057/biodiv/d200921.
Rosalina D, Herawati EY, Musa M, Sofarini D, Amin M, Risjani Y. 2019b. Lead accumulation and its histological impact on Cymodocea serrulata seagrass in the laboratory. Sains Malaysiana 48 (4): 813822. DOI: $10.17576 /$ jsm-2019-4804-13.

Saenger P, Gartside D, Funge-Smith S. 2013. A Review of Mangrove and Seagrass Ecosystems and Their Linkage to Fisheries and Fisheries Management. FAO Regional Office for Asia and the Pacific, Bangkok.

Schmidt AL, Wysmyk JKC, Craig SE, Lotze HK. 2012. Regional-scale effects of eutrophication on ecosystem structure and services of seagrass beds. Limnol Oceanogr 57: 1389-1402. DOI: 10.4319/lo.2012.57.5.1389.

Segovia-Rivera V, Valdivia N. 2016. Independent effects of grazing and tide pool habitats on the early colonization of an intertidal community on western Antarctic Peninsula. Rev Chil Hist Nat 9 (3): 1-9. DOI: 10.1186/s40693-016-0053-y.

Shelton AO, Francis TB, Feist BE, Williams GD, Lindquist A, Levin PS. 2016. Forty years of seagrass population stability and resilience in an urbanizing estuary. J Ecol 105 (2): 458-470. DOI: 10.1111/13652745.12682 .

Sugianti Y, Muntalif BS, Sudjono P. 2018. Periphyton response analysis to the pollution in seagrass ecosystem Panjang Island, Banten. Ilmu Kelautan 23 (3): 113-118. DOI: 10.14710/ik.ijms.23.3.113-118. [Indonesian]

van Tussenbroek BI, Cortés J, Collin R, Fonseca AC, Gayle PM, Guzmán HM, Jácome GE, Juman R, Koltes KH, Oxenford HA, RodríguezRamirez A, Samper-Villarreal J, Smith SR, Tschirky JJ, Weil E. 2014. Caribbean-wide, long-term study of seagrass beds reveals local variations, shifts in community structure and occasional collapse. Plos One 9 (3): e98377. DOI: 10.1371/journal.pone.0090600.

Yadav R, Kumar P, Saini VP, Sharma BK. 2017. Importance of periphyton for aquaculture. Aqua Star 12: 1-9. 